\title{
Evaluating the Responsiveness Level of a Training Program for General School Managers in Southern Vietnam
}

\author{
Huong Vu Thi Lan \\ Faculty of Education, University of Social Sciences \& Humanities \\ Vietnam National University, Ho Chi Minh \\ E-mail: lanhuong04at@gmail.com
}

Received: November 30, 2018 Accepted: July 20, 2019 Published: July 26, 2019

doi: $10.5296 /$ ire.v7i2.13978

URL: https://doi.org/10.5296/ire.v7i2.13978

\begin{abstract}
The purpose of this article is to present the results of a mixed methods research study conducted by the Ministry of Education and Training to evaluate the responsiveness level of a refresher programs for general school managers in Southern Vietnam. The program was designed to improve the capacities of managers in general schools to take the initiative in innovating leadership and management that will develop the schools and thereby advance the fundamental and comprehensive innovation of Vietnam's education system training programs.
\end{abstract}

Keywords: responsiveness level, training program, educational management, training program for general school managers

\section{Introduction}

At present, the Vietnam system of education is renovating so that it could complete the connection of educational organizations in order to meet the needs of the society, learners and globalization. General evaluation and evaluation of program response in particular is an integral part of the evaluation process. Evaluating the responsiveness level of program is a very important part of training process. "Responsiveness level" means in Vietnam is the process which the information and data are collected through a certain level. Based on this process the competent organizations and managers adjust the activities in order to meet the requirements, expectations and enhance the quality of the program.

Evaluating the responsiveness level in relation to Learners' and Users' needs which is a practical basis for improving program in fact innovation education in Vietnam. 


\section{Macrothink}

The Ministry of Education and Training (2015) decided that in order to innovate the educational system. The first step is to improve educational management and the capabilities of managers. The educational manager should have the qualities and skills that match social requirements. Furthermore, the managers should have the same starting point, which means they should be skilled teachers and ambitious about working for their community. The quickest way to help educational managers to fulfill their obligation is to provide an effective training program.

The Minister of Education and Training enacted a training program for managers of institutions in 2012. The program, named 382, was developed based on standard skills needed by principals in high schools and primary schools. Ultimately, the educational managers in general schools (high school and primary schools) need to develop their leadership capacity and management skills.

Therefore, Program 382 is targeted:

a) To improve the capacities of managers in general schools to take the initiative in innovating leadership and management;

b) To develop the schools in a way that advances the fundamental and comprehensive innovation Vietnam's education system. The combination of vision and action, school improvement and support of social values will elevate the quality of education. It advances the nation toward greater international integration.

Recently, a variety of problems were identified in several areas of the training program. including the target, content, method of teaching and method of examination and evaluation. The program 382 did not seem to be producing the desired practical changes in innovating education and supporting international integration. Therefore, the author and teammates (2016) decided that a program evaluation was needed.

In order to evaluate the responsiveness level of the training program for general school managers in Southern Vietnam, three questions needed to be answered:

1) Did the training program help the Learners (general school managers) and User (local government) to meet their needs?

2) At which responsiveness level was the training program evaluated?

3) What changes are needed for the training program to match the expectations of the Learners and Users?

To answer these questions, we needed to:

- Specify the factors to be used in evaluating the responsiveness level of the training program

- Specify the indexes to evaluate the responsiveness level of the training program

- Specify the information sources to evaluate the responsiveness level of the training program

\section{Research Design}

\subsection{Purpose}

The purpose of the research study: 1) To evaluate the responsiveness level of the training program; 2) To solicit suggestions from the general school managers to improve the outcomes 
of the training program.

Researchers at the Institute of Education Management in Ho Chi Minh City (IEMH) analyzed the data to evaluate the responsiveness level of Program 382. This analysis was performed based on several factors: purpose, content, method, vehicles and the method of examination and evaluation. In the area of research, they also collected the data from 6 cities which were in Southwest and Southeast of Vietnam. The program was launched since 2012.

\subsection{Method}

The research was performed using two main methods: a survey and deep interviews. Ten interviews were conducted with educational managers after the survey to clarify or confirm findings from the survey. The study had 787 participants including learners, managers of the Department of Education and training, and lecturers from IEMH. The survey scale was established on a convention based on an average value in the Linkert scale of 5 with the range value (Maximum-Minimum) $/ \mathrm{n}=(5-1) / 5=0.8$. The meaning of the answers on the scalewas1.000-1.80: Not satisfied; 1.81-2.60: Less satisfied; 2.61-3.40: Comparatively satisfied; 3.41-4.20: Satisfied; and 4.21-5.00: Very satisfied.

The research team built the research tools based on the responsiveness level of the training program for the managers in schools. The research protocol contained seven factors:

$1^{\text {st }}$ factor: Evaluating the general and specific target

$2^{\text {nd }}$ factor: Evaluating the content of the program

$3^{\text {rd }}$ factor: Evaluating the method of teaching

$4^{\text {th }}$ factor: Evaluating the organizational design

$5^{\text {th }}$ factor: Evaluating the testing and assessment of learning outcomes

$6^{\text {th }}$ factor: Evaluating the support methods for teaching

$7^{\text {th }}$ factor: Evaluating the obtained skills of the learners after the program.

\section{The Responsiveness Level of the Training Program}

The responsiveness level of the training program for the managers in schools contained seven factors as following:

\subsection{Training Target Fulfillment}

Table 1. The response level in training program

\begin{tabular}{|c|c|c|c|c|c|c|c|c|c|}
\hline \multirow{2}{*}{ No } & \multirow{2}{*}{ Content } & \multicolumn{4}{|c|}{ Senior learners } & \multicolumn{4}{|c|}{ Learners } \\
\hline & & Min & Max & Mean & SD & Min & Max & Mean & SD \\
\hline 1 & Specific and clearly & 3 & 5 & 4.63 & .674 & 3 & 5 & 4.70 & .658 \\
\hline 2 & $\begin{array}{l}\text { Fitting the requirements of } \\
\text { innovating the education }\end{array}$ & 1 & 4 & 2.30 & .613 & 2 & 4 & 2.36 & .560 \\
\hline 3 & $\begin{array}{l}\text { Fulfilling the needs of the } \\
\text { learners }\end{array}$ & 2 & 5 & 3.23 & .720 & 2 & 5 & 3.30 & .646 \\
\hline 4 & $\begin{array}{l}\text { Equipping knowledge } \\
\text { technique based on principal } \\
\text { standard }\end{array}$ & 2 & 4 & 3.7 & .652 & 2 & 4 & 3.53 & .647 \\
\hline
\end{tabular}




\section{Macrothink}

\begin{tabular}{llllllllll}
\hline 5 & $\begin{array}{l}\text { Fitting the educational 1 } \\
\text { integration regionally and } \\
\text { internationally }\end{array}$ & & & & & & & & \\
6 & $\begin{array}{l}\text { Fitting the skills and method } 1 \\
\text { of working to match the } \\
\text { requirements and missions }\end{array}$ & & 3.27 & .867 & 1 & 5 & 3.33 & .844 \\
\hline
\end{tabular}

For the group of learners which are Senior Learners and Learners, we considered the differences in the content of evaluation based on seniority, which relates to experience. Deep analysis ANOVA of the response level in the $5^{\text {th }}$ content area - "Fitting the educational integration regionally and internationally" - shows the differences in estimating the response level between Senior Learners and Learners with different seniority.

A learner group that contained a variety of people such as managers, teachers were established to consider responses in relation to the person's position. Deep analysis ANOVA showed that there is no difference in the response level based on a manager's position.

The $2^{\text {nd }}$ and $5^{\text {th }}$ criteria have the lowest score "Less satisfied," - while the $3^{\text {rd }}, 4^{\text {th }}$, and $6^{\text {th }}$ criteria are evaluated estimated to be "Comparatively satisfied".

In order to clarify the "Less satisfied" evaluation, deep interviews were conducted. Those interviewed thought that Program 382 was no longer current. Program 382 was enacted in 2012, and in the past 5 years the Government has been promulgating various policies to innovate the Vietnam system of education. Contemporaneously, the effect of internationalization and integration has resulted in changes. Even the principal standard is being reconstructed. Eventually, six training target criteria from the training program and the results of this survey show that it is necessary to make revisions and to add targets to the training program for general school managers. However, when a program's targets are changed, this also leads to changes in other program factors (Oliva, 1997).

\subsection{Training Content Fulfillment}

Sixteen (16) content factors are listed in order to estimate the response level in Table 2.

Table 2. The fulfillment in training content

\begin{tabular}{|c|c|c|c|c|c|c|c|c|c|}
\hline \multirow[b]{2}{*}{ No } & \multirow[b]{2}{*}{ Contents } & \multicolumn{4}{|c|}{ Senior Learners } & \multicolumn{4}{|c|}{ Learners } \\
\hline & & Min & $\operatorname{Max}$ & Mean & $S D$ & Min & $\operatorname{Max}$ & Mean & $S D$ \\
\hline 1 & $\begin{array}{l}\text { The program's content } \\
\text { matches with the training } \\
\text { target }\end{array}$ & 1 & 5 & 3.05 & .912 & 1 & 5 & 3.11 & .892 \\
\hline 2 & $\begin{array}{l}\text { The program's content is } \\
\text { always up-to-date }\end{array}$ & 1 & 5 & 2.54 & .980 & 1 & 5 & 2.62 & 1.031 \\
\hline 3 & $\begin{array}{l}\text { Reasonable number of } \\
\text { subjects in the program. }\end{array}$ & 1 & 5 & 3.59 & .839 & 1 & 5 & 3.63 & .832 \\
\hline 4 & $\begin{array}{l}\text { The balance between the } \\
\text { theory and the practical } \\
\text { training }\end{array}$ & 1 & 5 & 2.55 & 1.172 & 1 & 5 & 2.70 & 1.163 \\
\hline
\end{tabular}


5 The program has established the standard outputs in knowledge, skills, quality from the learners

6 The content is integrated with the knowledge, skills and responding skills in the principal standard

$\begin{array}{lllllllllll}7 & \text { The program's subjects are } & 1 & 5 & 2.73 & .907 & 1 & 5 & 2.80 & .942\end{array}$ systematically organized

$\begin{array}{lllllllllll}8 & \text { The program's content is } & 1 & 5 & 2.71 & .928 & 1 & 5 & 2.81 & 1.007\end{array}$ open

$\begin{array}{llllllllll}9 & \text { The subjects are integrated, } 1 & 5 & 2.90 & 1.088 & 1 & 5 & 2.94 & 1.086\end{array}$ supportive and consolidated

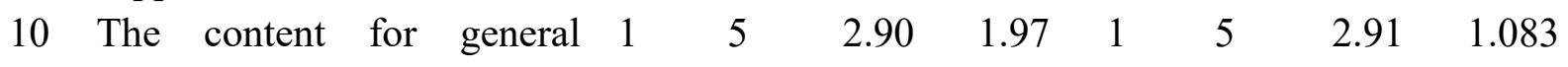
knowledge and management skills for school managers and supportive skills is balanced

11 The practice in program's $1 \quad \begin{array}{llllllll}5 & 2.76 & 1.144 & 1 & 5 & 2.84 & 1.148\end{array}$ content

$\begin{array}{llllllllll}12 & \text { The necessary in program's } & 1 & 5 & 2.94 & 1.088 & 1 & 5 & 2.91 & 1.083\end{array}$ content is relevant

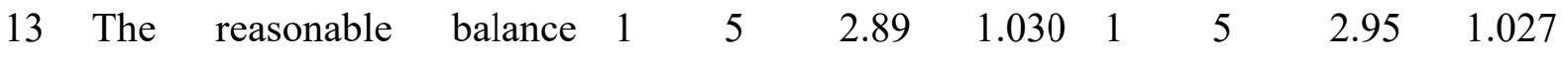
between theory and practical training

14 The program's $\begin{array}{llllllllll} & \text { content } & 1 & 5 & 2.86 & 1.051 & 1 & 5 & 2.92 & 1.053\end{array}$ matches with the learner's expectations

$\begin{array}{llllllllll} & \text { The program's content and } 1 & 5 & 2.92 & 1.163 & 1 & 5 & 2.92 & 1.173\end{array}$ the training duration are balanced

$\begin{array}{llllllllll} & \text { The program matches with } & 1 & 5 & 2.81 & 1.086 & 1 & 5 & 2.84 & 1.071\end{array}$ the requirement based on the principal standard

In the 16 criteria, only the $3^{\text {rd }}$ criteria has the average scores of 3.59 and 3.63 which refers to "satisfied". The rest of the criteria are considered as "comparatively satisfied". The $6^{\text {th }}$ criteria is considered to be "Less satisfied" with 2.38 and 2.47.

Deep analysis ANOVA showed differences in response levels in the $4^{\text {th }}$ criteria between principals and vice-principals which belong to Senior Learners based on their management seniority. There is no difference in responsiveness level in managerial position between Senior Learners and Learners. 


\subsection{Training Methods Fulfillment}

The third factor: training methor fulfillment to estimate the response level in Table 3.

Table 3. The fulfillment in training methods

\begin{tabular}{|c|c|c|c|c|c|c|c|c|c|}
\hline \multirow[t]{2}{*}{ No } & \multirow[t]{2}{*}{ Content } & \multicolumn{4}{|c|}{ Senior Learners } & \multicolumn{4}{|c|}{ Learners } \\
\hline & & $\operatorname{Min}$ & $\operatorname{Max}$ & Mean & $S D$ & Min & $\operatorname{Max}$ & Mean & $S D$ \\
\hline 1 & Clear and understandable & 1 & 5 & 3.44 & 1.060 & 1 & 5 & 3.04 & 1.152 \\
\hline 2 & $\begin{array}{l}\text { The relationship between the } \\
\text { theory and practical training }\end{array}$ & 1 & 5 & 3.22 & .933 & 1 & 5 & 2.81 & .938 \\
\hline 3 & $\begin{array}{l}\text { Promoting the positiveness } \\
\text { of the learners }\end{array}$ & 1 & 5 & 3.11 & 1.062 & 1 & 5 & 2.55 & .992 \\
\hline 4 & $\begin{array}{l}\text { Creating an open study } \\
\text { environment }\end{array}$ & 1 & 5 & 3.44 & .959 & 1 & 5 & 3.04 & .980 \\
\hline 5 & $\begin{array}{l}\text { Encouraging the learners to } \\
\text { be active and creative }\end{array}$ & 1 & 5 & 3.28 & .939 & 1 & 5 & 2.86 & .922 \\
\hline
\end{tabular}

There are differences in evaluating the training methods between 2 groups. The "Senior Learners" are evaluated as "comparatively satisfied" and "satisfied". The "Learners" group is evaluated to be "less satisfied" in the $3^{\text {rd }}$ criteria. The rest of the content is evaluated as "comparatively satisfied".

In reality, the faculties often choose the experienced teachers to teach the class "Advanced management skills in general schools". Educational management science is specific and the teachers need to be able to solve problems that come from real life situations. Less experienced teachers might have difficulty with finding the relationship between theory and practice. Results from the deep interviews clearly revealed this problem.

\subsection{The Responsiveness Level in the Forms of Training Organization}

Analysis results the responsiveness level in the forms of training organization are shown in Table 4 below.

Table 4. The responsiveness level in the forms of training organization

\begin{tabular}{|c|c|c|c|c|c|c|c|c|c|}
\hline \multirow[b]{2}{*}{ No } & \multirow[b]{2}{*}{ Content } & \multicolumn{4}{|c|}{ Senior Learners } & \multicolumn{4}{|c|}{ Learners } \\
\hline & & Min & $\operatorname{Max}$ & Mean & $S D$ & Min & $\operatorname{Max}$ & Mean & $S D$ \\
\hline 1 & 2-3 months in IEMH & 1 & 5 & 2.37 & 1.000 & 1 & 5 & 2.28 & .964 \\
\hline 2 & 2-3 times per course in IEMH & 1 & 5 & 2.71 & 1.049 & 1 & 5 & 2.67 & 1.057 \\
\hline 3 & 1-3 days per week in IEMH & 1 & 5 & 2.08 & .743 & 1 & 5 & 2.05 & .710 \\
\hline 4 & $\begin{array}{l}2-3 \text { months in the local } \\
\text { course }\end{array}$ & 1 & 5 & 2.77 & 1.048 & 1 & 5 & 2.74 & 1.50 \\
\hline 5 & $\begin{array}{l}2-3 \text { times per course in the } \\
\text { local course }\end{array}$ & 2 & 4 & 3.01 & .434 & 2 & 4 & 3.00 & .429 \\
\hline 6 & $\begin{array}{l}1-3 \text { days per week in the local } \\
\text { course }\end{array}$ & 1 & 5 & 3.32 & .929 & 1 & 5 & 3.32 & 9.28 \\
\hline
\end{tabular}


The $1^{\text {st }}$ and $3^{\text {rd }}$ criteria in both groups (Senior Learners and Learners) are "less satisfied" while the rest are "comparatively satisfied". Finding explored further in the interviews, we see that both groups liked the local training courses. They could participate training course and work in school.

\subsection{The Responsiveness Level in Testing and Evaluating the Training Program Results}

Analysis results the responsiveness level in testing and evaluating the training program results are shown in Table 5 below.

Table 5. The responsiveness level in testing and evaluating the result of training program

\begin{tabular}{|c|c|c|c|c|c|c|c|c|c|}
\hline \multirow[b]{2}{*}{ No } & \multirow[b]{2}{*}{ Content } & \multicolumn{4}{|c|}{ Senior Learners } & \multicolumn{4}{|c|}{ Learners } \\
\hline & & Min & $\operatorname{Max}$ & Mean & $S D$ & Min & $\operatorname{Max}$ & Mean & $S D$ \\
\hline 1 & $\begin{array}{l}\text { The procedure of the } \\
\text { evaluation matches with the } \\
\text { goals }\end{array}$ & 1 & 5 & 3.09 & 1.615 & 1 & 5 & 3.09 & 1.624 \\
\hline 2 & $\begin{array}{l}\text { Quantity of examinations at } \\
\text { the end of the modules }\end{array}$ & 1 & 5 & 3.19 & 1.736 & 1 & 5 & 3.18 & 1.748 \\
\hline 3 & $\begin{array}{l}\text { The regulations for writing } \\
\text { essays matches with the } \\
\text { learners }\end{array}$ & 1 & 5 & 2.34 & 1.412 & 1 & 5 & 2.30 & 1.420 \\
\hline 4 & $\begin{array}{l}\text { Evaluation methods are fair } \\
\text { and objective }\end{array}$ & 1 & 5 & 2.97 & 1.214 & 1 & 5 & 2.95 & 1.231 \\
\hline 5 & $\begin{array}{l}\text { The evaluation results are } \\
\text { valuable and trustworthy. }\end{array}$ & 1 & 5 & 2.78 & 1.410 & 1 & 5 & 2.79 & 1.413 \\
\hline 6 & $\begin{array}{l}\text { Results are announced to the } \\
\text { learners in reasonable time }\end{array}$ & 1 & 5 & 3.34 & .888 & 2 & 5 & 3.36 & .877 \\
\hline 7 & $\begin{array}{l}\text { The content of examination } \\
\text { and evaluation are relevant } \\
\text { to the training program }\end{array}$ & 1 & 5 & 3.81 & 1.086 & 2 & 5 & 3.32 & 1.077 \\
\hline 8 & $\begin{array}{l}\text { The method of testing is able } \\
\text { to evaluate the learner's } \\
\text { skills. }\end{array}$ & 1 & 5 & 2.33 & 1.219 & 1 & 5 & 2.33 & 1.223 \\
\hline 9 & $\begin{array}{l}\text { The method of testing is } \\
\text { diverse }\end{array}$ & 1 & 5 & 2.23 & 1.385 & 1 & 5 & 2.19 & 1.408 \\
\hline 10 & $\begin{array}{l}\text { The learners could use the } \\
\text { result of evaluation to adjust } \\
\text { their management skills in } \\
\text { reality }\end{array}$ & 1 & 5 & 3.03 & 1.288 & 2 & 5 & 3.05 & 1.265 \\
\hline
\end{tabular}

The $8^{\text {th }}$ and $9^{\text {th }}$ criteria in both groups are "less satisfied". In reality, many students in IEMH go to library and make a copy of essays from previous classes.

The $3^{\text {rd }}$ and $6^{\text {th }}$ criteria have shown a difference in response levels between two groups. The "Old students" are considered to be "less satisfied" while the "Students" group are 
"comparatively satisfied".

The rest of the content are "comparatively satisfied".

\subsection{Evaluating the Supporting Conditions in Training Program}

Evaluating the supporting conditions in training program are shown in Table 6 below.

Table 6. The supporting conditions in training program

\begin{tabular}{|c|c|c|c|c|c|c|c|c|c|}
\hline \multirow[b]{2}{*}{ No } & \multirow[b]{2}{*}{ Content } & \multicolumn{4}{|c|}{ Senior Learners } & \multicolumn{4}{|c|}{ Learners } \\
\hline & & Min & $M a$ & Mean & $S D$ & Min & $\operatorname{Max}$ & Mean & $S D$ \\
\hline 1 & $\begin{array}{l}\text { The classroom fulfills the } \\
\text { conditions such as seats, sound } \\
\text { and light. }\end{array}$ & 1 & 5 & 3.45 & .672 & 2 & 5 & 3.46 & .652 \\
\hline 2 & $\begin{array}{l}\text { The technology devices } \\
\text { support instruction well }\end{array}$ & 1 & 5 & 3.04 & 1.029 & 1 & 5 & 3.04 & 1.025 \\
\hline 3 & $\begin{array}{l}\text { The documents are up-to-date } \\
\text { and accurate in content }\end{array}$ & 1 & 5 & 2.59 & 1.013 & 1 & 5 & 2.59 & .989 \\
\hline 4 & $\begin{array}{l}\text { The learners feel confident in } \\
\text { accessing references and } \\
\text { websites }\end{array}$ & 1 & 5 & 2.74 & .826 & 1 & 5 & 2.73 & .809 \\
\hline
\end{tabular}

The $3^{\text {rd }}$ criteria is "less satisfied," which is a problem that IEMH should address. The documents that are handed to the learners were written and enacted in 2012 and have not been updated or edited. However, in some cases the documents could have been updated through the slides and presentations, although not officially updated. The rest of the content was evaluated as "comparatively satisfied".

Deep analysis ANOVA shows no difference in responses for these content areas between principals and vice-principals. To the Learner groups, the ANOVA shows that there is no difference in the evaluation of content between the job positions.

\subsection{The Skills That the Learners Would Obtain Upon Completing the Training Program}

The last factor: the skills that the learners would obtain upon completing the training program are shown in Table 7 below.

Table 7. The obtained skills upon completing training program

\begin{tabular}{|c|c|c|c|c|c|c|c|c|c|}
\hline \multirow[b]{2}{*}{ No } & \multirow[b]{2}{*}{ Content } & \multicolumn{4}{|c|}{ Senior Learners } & \multicolumn{4}{|c|}{ Learners } \\
\hline & & Min & $\operatorname{Max}$ & Mean & $S D$ & Min & $\operatorname{Max}$ & Mean & $S D$ \\
\hline 1 & $\begin{array}{l}\text { The ability to work in an } \\
\text { environment which has } \\
\text { various changes }\end{array}$ & 2 & 5 & 3.63 & .776 & 2 & 5 & 3.63 & .775 \\
\hline 2 & $\begin{array}{l}\text { The ability to conduct } \\
\text { self-study and self-research }\end{array}$ & 2 & 4 & 4.00 & .741 & 2 & 5 & 3.99 & .739 \\
\hline 3 & $\begin{array}{l}\text { The ability to organize and } \\
\text { carry out the missions }\end{array}$ & 1 & 5 & 3.50 & .947 & 1 & 5 & 3.50 & .946 \\
\hline
\end{tabular}


\begin{tabular}{lllllllllll}
\hline 4 & The ability to analyze, & 1 & 5 & 3.55 & 1.038 & 1 & 5 & 3.55 & 1.037
\end{tabular} evaluate and solve problems

$\begin{array}{llllllllll}5 & \text { The ability to communicate } & 1 & 5 & 3.36 & 1.233 & 1 & 5 & 3.36 & 1.232\end{array}$ and persuade

$\begin{array}{llllllllll}6 & \text { The ability to endure high } & 2 & 4 & 3.28 & .754 & 2 & 4 & 3.28 & .753\end{array}$ pressure while working

$\begin{array}{llllllllll}7 & \text { The ability to make plans, } & 1 & 5 & 3.36 & .985 & 1 & 5 & 3.36 & .984\end{array}$ organize, and manage assigned tasks

$\begin{array}{llllllllll}8 & \text { The ability to solve problems } & 1 & 5 & 3.36 & 1.030 & 1 & 5 & 3.36 & 1.028\end{array}$

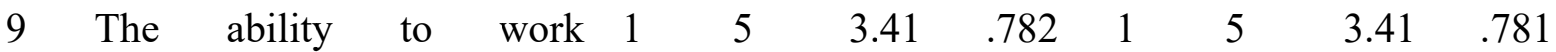
professionally

$\begin{array}{llllllllll}10 & \text { The ability to communicate } & 1 & 5 & 3.32 & .879 & 1 & 5 & 3.32 & .878\end{array}$ effectively

11 The ability to work $\begin{array}{lllllllll} & 1 & 5 & 3.46 & .946 & 1 & 5 & 3.46 & .945\end{array}$ independently

12 The ability to be creative and $\begin{array}{lllllllll}1 & 4 & 3.08 & .849 & 1 & 4 & 3.08 & .848\end{array}$ innovate

$\begin{array}{lllllllllll} & \text { The ability to } & \text { detect } & 1 & 5 & 3.68 & .824 & 1 & 5 & 3.68 & .823\end{array}$ problems

Both groups have the same results. Most of the content are "satisfied" and "comparatively satisfied".

For the Senior Learners group, the deep analysis ANOVA shows that the $6^{\text {th }}, 8^{\text {th }}, 12^{\text {th }}$, and $13^{\text {th }}$ content are based on management seniority. Regarding the Learners group, the ANOVA shows the differences in evaluation of the content areas as being related to the management positions in those contents (e.g., the $6^{\text {th }}, 8^{\text {th }}, 12^{\text {th }}$ criteria).

In order to objectively evaluate the skills that learners could obtain upon completing the training program, we compared 2 targets: learners and managers. The results are shown in Table 8.

Table 8. Comparison between the obtained skills

\begin{tabular}{|c|c|c|c|c|c|c|c|}
\hline \multirow[b]{2}{*}{ No } & \multirow[b]{2}{*}{ Content } & \multicolumn{3}{|c|}{ Learners } & \multicolumn{3}{|c|}{ Managers } \\
\hline & & Min & $\operatorname{Max}$ & Mean & Min & $\operatorname{Max}$ & Mean \\
\hline 1 & $\begin{array}{l}\text { The ability to work in an environment which } \\
\text { has various changes }\end{array}$ & 2 & 5 & 3.63 & 2 & 4 & 3.48 \\
\hline 2 & $\begin{array}{l}\text { The ability to conduct self-study and } \\
\text { self-research }\end{array}$ & 2 & 4 & 4.00 & 2 & 5 & 3.76 \\
\hline 3 & $\begin{array}{l}\text { The ability to organize and carry out the } \\
\text { missions }\end{array}$ & 1 & 5 & 3.50 & 2 & 5 & 3.71 \\
\hline 4 & $\begin{array}{l}\text { The ability to analyze, estimate and solve } \\
\text { problems }\end{array}$ & 1 & 5 & 3.55 & 2 & 4 & 3.71 \\
\hline
\end{tabular}




\begin{tabular}{llllllll}
\hline 5 & $\begin{array}{l}\text { The ability to communicate and persuade } \\
6\end{array}$ & 1 & 5 & 3.36 & 2 & 5 & 3.48 \\
$\begin{array}{l}\text { The ability to endure the high pressure while } \\
\text { working }\end{array}$ & 2 & 4 & 3.28 & 2 & 5 & 3.81 \\
7 & $\begin{array}{l}\text { The ability to make plans, organize, and } \\
\text { manage assigned tasks }\end{array}$ & 1 & 5 & 3.36 & 2 & 5 & 3.57 \\
8 & The ability to solve problems & 1 & 5 & 3.36 & 2 & 4 & 3.71 \\
9 & The ability to work professionally & 1 & 5 & 3.41 & 2 & 5 & 3.76 \\
10 & The ability to communicate effectively & 1 & 5 & 3.32 & 2 & 5 & 3.76 \\
11 & The ability to work independently & 1 & 5 & 3.46 & 2 & 5 & 3.71 \\
12 & The ability to be creative and innovate & 1 & 4 & 3.08 & 2 & 5 & 3.62 \\
13 & The ability to detect problems & 1 & 5 & 3.68 & 2 & 5 & 3.95 \\
\hline
\end{tabular}

The comparison between 2 targets shows that:

The Learner group has the highest average score -4.00 for the ability to self-study and self-research and 3.08 for the ability to be creative and innovate.

The Managers group has the highest average score -3.95 for the ability to detect problems and lowest-3.48 in the ability to work in an environment which has various changes.

The obtained skills show the differences in evaluation between the Learner group and the Managers group. As found in the interviews, this difference was based on their positions and the way to approach and solve problems in the relationship between managers and management targets.

In reality, after completing the training program, the learners are able to apply the knowledge and skills they have learned to their work and they are appreciated by their superiors, as revealed in the interviews.

The result from the target which uses the human-resource in the learner's skill after graduating from Program 382 is worth considering when adjusting the training program for general school managers.

\section{The Suggestions for the Training Program for General School Managers}

The results of this research study suggest recommendations for improving the training program.

\subsection{The Target}

The principal and vice-president are the managers in institutions; however, the demands of their positions require different training content that directly relates to the system capacity of education managers. In addition to techniques, human relations and general skills are needed for adaptation to a constantly changing environment.

The target of Program 382 focuses on developing the managers' skills; therefore, the subjects should point to knowledge, essential skills, responsibilities, and missions of today's managers.

The desired output of the program should be constructed when developing the target.

\subsection{The Content}

The requirements in skills, knowledge, and attitudes are not compatible with the requirements 
in the principal standard. Subjects related to adaptation skills based on the principal standard should be added to the program. For example:

- Applying professional ethics;

- Analyzing life styles and communications;

- Handling conflicts;

- Constructing and developing programs;

- Managing and organizing programs;

- Analyzing and forecasting.

\subsection{The Method of Training}

The highest priority recommendation is to calibrate the teaching methods for these particular students. These students are adults, experienced managers, and teachers who have a deep knowledge of techniques and practice. The training methods need to be:

- Motivational and draw out the creativity of the learners;

- $\quad$ Point to the core problems

- Demonstrate the relationship between theory and reality throughout the assignments by using real-life problems.

\subsection{The Method of Organizing the Training Program}

The training program needs to be diverse and based on the practical requirements of the Learners. The method of organizing the program should let the learners be the center and the program should serve the learners.

\subsection{Inspecting and Evaluating the Results of the Training Program}

- Use diverse methods to inspect and evaluate the outcomes of the instruction. For example, a bank of questions in multiple choice examinations could be used along with essays upon finishing a module.

- Assign the learners a Self-selected essay topic, and let them choose their own problems and solutions.

- Replace the last essay with a project that matches their positions.

\subsection{The Supporting Conditions for the Training Program}

- Assure and enhance the quality of the training program. For instance, the organizations and individuals when signing the contract for the training program need to add more terms such as:

- The technology devices for teaching and training need to be compatible with the resources of the institution offering the program.

- The program documents need to be up-to-date and have accurate content.

- The learners should have opportunities to access reference documents and websites.

4.7 Skills

Upon completing the training program, the learners should have these skills:

- The ability to persuade and communicate

- The ability to endure the high pressure of their work 
- The ability to plan, organize and manage assigned tasks

- The ability to solve problems

- The ability to communicate effectively.

\section{Conclusion}

In order to evaluate the responsiveness level of a training program for managers in general schools based on decision 382/2012/QĐ-BGDĐT, the research team constructed a survey instrument. The research team built the research tools based on the responsiveness level of the training program for the managers in schools. The research protocol contains seven factors: 1/ Evaluating the general and specific target;2/Evaluating the content of the program; 3/Evaluating the method of teaching; 4/Evaluating the organizational design; 5/Evaluating the testing and assessment of learning outcomes; 6/Evaluating the supporting methods for teaching; 7/Evaluating the obtained skills of the learners after the program.

The research team analyzed the responsiveness in specific program areas: targets, contents, methods, organizations and evaluation, as shown in this brief overview. The skills which could be obtained upon completing the program have been clearly shown by the organizations, units and learners themselves. From the research, legal documents and analysis, the research team has made recommendations in 3 areas to improve the training program in general schools: 1 / management operations (6 small solutions); 2 / training (7 small solutions); and 3 / conditions ( 3 small solutions).

\section{References}

About The Standards. Common Core State Standards Initiative. Retrieved from http://www.corestandards.org/read-the-standards/

Darling-Hammond, L., LaPointe, M., Meyerson, D., Orr. M. T., \& Cohen, C. (2007). Preparing school leaders for a changing world: Lessons from exemplary leadership development programs, Stanford Education Leadership Institute.

Ministry of Education and Training. (2009). Standard of Principals of lower secondary schools, high schools and high schools with many levels of education.

Ministry of Education and Training. (2011). Standard of Principals of primary schools.

Ministry of Education and Training (2012). Training program for managers in high schools.

McCormick Foundation, Program Evaluation Guide. Retrieved from http://documents.mccormickfoundation.org/pdf/EvaluationGuide_6.19.13.pdf

Ministry of Education and Training. (2015). Yearbook Enhancing the training skills for teachers and educational staffs in institutions to response to requirements in general education, Da Nang.

National Board of Professional Teacher Standards. National Board of Professional Teacher Standards. https://www.nbpts.org/standards-five-core-propositions/

Nguyen, Đ. C., \& Vu, L. H. (2015). Educational program development. Publishing House Vietnam Education.

Peter, F. O. (1997). Developing the curriculum (4th ed.). Longman.

Prime, M. (2012). Decision 711/2012/QĐ-TTg Vietnam education development strategy 2011-2020. 


\section{Macrothink

Vu, L. H. (2018). Evaluating the responsiveness level of a training program for general schools managers based on Decision 382/2012/QĐ-BGDĐT in Southern Vietnam.

Vu, L. H., \& Le, T. N. N. (2017). Training school managers in South Korea. International Conference, Training and Professional Developmant For Teachers, Principal advisors and education Lecturers.

\section{Copyright Disclaimer}

Copyright reserved by the authors.

This article is an open-access article distributed under the terms and conditions of the Creative Commons Attribution license (http://creativecommons.org/licenses/by/3.0/). 